\title{
Responses of Avicennia germinans (Black Mangrove) and the Soil Microbial Community to Nitrogen Addition in a Hypersaline Wetland
}

\author{
Dennis F. Whigham • Jos T. A. Verhoeven • \\ Vladimir Samarkin • Patrick J. Megonigal
}

Received: 14 October 2008 /Revised: 28 March 2009/Accepted: 30 May 2009 /Published online: 18 June 2009

(C) The Author(s) 2009. This article is published with open access at Springerlink.com

\begin{abstract}
The responses of dwarf black mangroves (Avicennia germinans) and components of the microbial community to the addition of nitrate over a 2-year period were examined. The field study was conducted in the Indian River Lagoon (Florida) in a mangrove-dominated impoundment that was established for purposes of mosquito control. The responses of mangroves to the regular addition of nitrate were insignificant or relatively minor compared to responses of the components of the microbial community. Denitrification rates, measured in the field and laboratory, increased significantly in fertilized plots and nitrous oxide emission rates were almost six times higher in fertilized plots. Nitrogen fixation was significantly lower in fertilized plots. Results suggest that mangrove systems in the N-limited Indian River Lagoon are likely to be longterm sinks for any increases in $\mathrm{N}$ loading.
\end{abstract}

Keywords Avicennia germinans · Mangrove · Florida · Denitrification · Nitrogen fixation - Microbial community

D. F. Whigham $(\bowtie) \cdot$ V. Samarkin $\cdot$ P. J. Megonigal

Smithsonian Environmental Research Center,

Edgewater, MD 21037, USA

e-mail: whighamd@si.edu

J. T. A. Verhoeven

Landscape Ecology, Institute of Environmental Biology,

Utrecht University,

Utrecht 3508 TB, The Netherlands

Present Address:

V. Samarkin

Department of Marine Sciences,

University of Georgia,

Athens, GA 30602, USA

\section{Introduction}

Salinity and nutrient availability have a major influence on the structure and function of mangrove ecosystems. Nitrogen $(\mathrm{N})$ and phosphorus $(\mathrm{P})$ availability limit mangrove productivity (Boto and Wellington 1983; Chen and Twilley 1999; Feller et al. 1999; Feller et al. 2003) and growth form (Feller 1995). Salinity also affects production and growth form as well as mangrove mortality. Dwarf (scrub) growth forms are typically associated with highly saline habitats (Castaneda-Moya et al. 2006; Nandoo 2006; Sobrado and Ewe 2006). Increasing salinity causes height and growth to decrease, especially of Avicennia species (Ye et al. 2005; Lara and Cohen 2006; López-Hoffman et al. 2007), and mortality to increase (Suárez and Medina 2005).

Nutrient limitations have been shown to vary in space even where no strong salinity gradient exists (Feller et al. 2002; Lovelock et al. 2006a). In Belize, the growth of tall $(4-7 \mathrm{~m})$ red mangroves (Rhizophora mangle L.Rhizophoraceae) was $\mathrm{N}$-limited near the shoreline where interstitial salinity averaged 35-37 (Lovelock et al. 2006a). At the interior end of the study transects, salinity was only two to three units higher but the red mangroves averaged $\leq 1.5 \mathrm{~m}$ tall and were strongly limited by $\mathrm{P}$ availability. Adding $\mathrm{P}$ to dwarf trees in the interior zone results in a significant increase in growth and the trees became much taller and larger (Feller 1995).

In a related study in the Indian River Lagoon in Florida, shoot growth of red and black (Avicennia germinans (L.) Stearn-Avicenniaceae) mangroves at all locations along a tree-height gradient was limited by $\mathrm{N}$ availability and the greatest response to $\mathrm{N}$ addition occurred in dwarf black mangroves that occurred toward the interior of the wetland (Feller et al. 2003; Lovelock et al. 2006b. In contrast to the lack of a clear salinity pattern along the transects in Belize 
(see above), there was a distinct salinity gradient at the Florida study site with salinity ranging from 39-40 in the tall red mangrove zone to $49-57$ in the area dominated by dwarf mangroves (Feller et al. 2003).

The mechanisms by which nutrients and salinity interact to influence mangrove growth have not been well studied, but studies tend to focus on plant physiological processes. For example, Lovelock et al. (2006b) found that the mechanisms by which mangrove species respond to increasing salinity vary according to the prevailing limiting nutrient. In P-limited habitats, they concluded that internal processes that control the movement of water throughout the plants (e.g., hydraulic conductivity) have an important control over productivity. In contrast, in N-limited habitats where salinity varied across the study sites, patterns of allocation of leaf area and adjustments to photosynthetic rates were more important than hydraulic conductivity.

Microbial responses to nutrient and salinity gradients have the potential to indirectly affect mangrove productivity through their influence on nutrient availability. In the context of $\mathrm{N}$ availability, the most fundamental microbial processes that regulate the long-term $\mathrm{N}$ balance of ecosystems are $\mathrm{N}$ fixation, which adds available $\mathrm{N}$ to the ecosystem, and denitrification, which removes N. Nitrogen fixation can be high in N-limited mangrove systems (Lee and Joye 2006) and a significant source of available $\mathrm{N}$ in dwarf mangrove habitats (Hicks and Silvester 1985; Joye and Lee 2004). The presence of $\mathrm{N}$-fixing bacteria and cyanobacteria, for example, improved the nitrogen economy of Avicennia seedlings (Toldeo et al. 1995; Bashan et al. 1998). Nitrification and denitrification are relatively low in mangrove sediments (Zuberer and Silver 1979; RiveraMonroy et al. 1995; Pelegraí et al. 1997; Kristensen et al. 1998; Bauza et al. 2002) and microbial mats (Lee and Joye 2006), but denitrification increases significantly when $\mathrm{N}$ is provided as nitrate to the microbial community (Corredor et al. 1999; Muñoz-Hincapié et al. 2002; Chiu et al. 2004; Allen et al. 2007). High rates of microbially mediated nutrient sequestration (Alongi et al. 2005; Rivera-Monroy and Twilley 1996) and mineralization (Alongi et al. 2005) occur when mangroves receive nutrients from human activities.

In this study, we measured the responses of individual dwarf black mangroves and the microbial communities responsible for denitrification and nitrogen fixation, two of the key microbial processes related to the $\mathrm{N}$ cycle. Nitrogen was applied to plots that each contained a single dwarf black mangrove over a 2-year period in a high salinity habitat in an N-limited ecosystem. Based on previous studies of $\mathrm{N}$ addition to mangrove systems, we anticipated that both components of the system (i.e., the microbial community and the dwarf black mangroves) would respond to the addition of $\mathrm{N}$. However, we predicted that the Nfixation and denitrifier communities would respond quickly to the addition of $\mathrm{N}$, intercepting it and limiting the response of fertilization on the dwarf mangroves.

\section{Study Site}

The study was conducted in a mangrove ecosystem in a mosquito control impoundment (SLC-24), which is located at $\mathrm{N} 27^{\circ} 33^{\prime}, \mathrm{W} 80^{\circ} 33^{\prime}$ on the Atlantic Ocean side of the Indian River Lagoon (IRL) on North Hutchinson Island in St. Lucie County between Ft. Pierce and Vero Beach, Florida. The Ft. Pierce area has a subtropical climate with average annual, maximum, and minimum temperatures of approximately 23,28 , and $18^{\circ} \mathrm{C}$. Precipitation has a strong seasonal component. The annual average (approximately $1,340 \mathrm{~mm}$ ) is distributed over an extended relatively dry period (November-May long-term mean is $523 \mathrm{~mm}$ ) and a shorter rainy season (June-October long-term mean $814 \mathrm{~mm})$. December is the driest month (mean=51 mm) and September the wettest (mean $=202 \mathrm{~mm}$ ).

SLC-24 was developed in 1970 by building a dike that isolated an existing mangrove-dominated wetland from the IRL (Rey et al. 1990). SLC-24 was isolated from the IRL between 1970 and 1985. A culvert was installed in the dike in 1985 to remove excess water that had accumulated during two tropical storms. The culvert was closed and SLC-24 remained isolated until 1987 when the original culvert was reopened and four additional culverts were added. Vegetation cover in SLC-24 decreased from 75\% to near 30\% between 1970 and 1985 (Rey et al. 1990) but began to recover following the installation of the culverts that allowed a tidal connection between SLC-24 and the IRL. Tidal exchange is, however, limited because of the small number and size of the culverts. Tidal fluctuations are almost always less than $50 \mathrm{~cm}$. The sandy soils have a low organic matter content (typically less than 5\%; Feller et al. 2003).

Black mangrove is the dominant species in SLC-24 but red and white (Laguncularia racemosa L.-Combretaceae) mangrove and buttonbush (Conocarpus erecta L.Combretaceae) are also present and, in a few areas, the dominant species (D. Whigham, personal observation). The dominant understory plant throughout SLC-24 is Batis maritima L. and other common understory species are Salicornia virginica L. (Chenopodiaceae), Salicornia bigelovii Torr. (Chenopodiaceae), and Borrichia frutescens (L.) DC. (Asteraceae).

Earlier research in impoundment SLC-23, immediately adjacent to SLC-24, had clearly shown that nitrogen limited the growth of dwarf, intermediate, and tall black and red mangroves at the creek margin, the transition zone between the creek and the wetland interior and the wetland interior (Feller et al. 2003; Lovelock and Feller 2003; Lovelock et al. 2006b). 
Table 1 Characteristics of Fertilized and Control plots at the beginning of the two year experiment

\begin{tabular}{lll}
\hline Variable & Control plots & Fertilized plots \\
\hline Leaf N (\%) & $1.57 \pm 0.06$ & $1.59 \pm 0.03$ \\
Soil temp (C) & $22.7 \pm 0.05$ & $22.8 \pm 0.09$ \\
$\mathrm{pH}$ & $7.57 \pm 0.10$ & $7.51 \pm 0.05$ \\
Salinity (ppt) & $58.3 \pm 1.56$ & $56.4 \pm 1.86$ \\
Eh (mV) & $93.8 \pm 10.6$ & $131.4 \pm 13.3$ \\
Sulfide (mM) & $\mathrm{nd}^{\mathrm{a}}$ & $\mathrm{nd}$ \\
Nitrate (mg/l) & $2.74 \pm 1.13$ & $5.48 \pm 1.03$ \\
Ammonium (mg/l) & $1.03 \pm 0.29$ & $1.21 \pm 0.48$ \\
Number Batis maritima & $29.7 \pm 6.7$ & $29.9 \pm 8.3$ \\
Cover of Salicornia spp. (\%) & $19.2 \pm 6.6$ & $16.4 \pm 3.3$ \\
\hline
\end{tabular}

Plots were sampled the first day that 51 of estuarine water from the Indian River (with or without fertilizer added) was added (February 7 , 2001)

nd none detected

${ }^{\text {a }}$ During the same period of time that soil samples were collected from the 12 plots, we collected groundwater from three shallow wells near the plots. Sulfide concentrations were nd, 0.05 , and $0.85 \mathrm{mM}$

\section{Experimental Design}

The fertilization study was conducted in an area dominated by dwarf black mangroves. Table 1 provides initial conditions in the twelve $1 \times 1 \mathrm{~m}$ study plots that were each centered on one dwarf black mangrove. Treatments were randomly assigned to the plots $(N=$ six fertilized and six controls) and the experiment was started in February, 2001. Plots were watered on a monthly basis, except during a month or two each year when there was standing water in the impoundments, with 51 of IRL water (controls) or 51 of IRL water in which $6 \mathrm{~g}$ of $\mathrm{NaNO}_{3}$ was dissolved. Total $\mathrm{N}$ addition to each fertilized plots was $10 \mathrm{gN} / \mathrm{m}^{2} /$ year. Treatments ended in February 2003.

\section{Methods}

\section{Mangrove Measurements}

Prior to the start of the experiment, three shoots on each black mangrove (hereafter referred to as Avicennia) were tagged for annual measurements of leaf production (number of new leaves produced/year), branch production (number of new branches produced/year) and shoot growth (increase in shoot length in $\mathrm{cm} /$ year) using procedures described in Feller et al. (2003). Shoots were re-measured in February 2002 and 2003. In February of 2001 and 2003, we collected ten senesced leaves from each plant for $\mathrm{N}$ determination (no senesced leaves were present during the February 2002 sampling period). The composite leaf samples were dried at $60^{\circ} \mathrm{C}$ and analyzed for N with a Perkin-Elmer 2400 CHN Analyzer after they were ground in a Wiley Mill $(0.38 \mathrm{~mm}$ mesh).

At the beginning of the experiment, we also surveyed other vascular plants in the plots. The number of individually rooted B. maritima shoots in each plot was counted and the percent cover for species of Salicornia was visually estimated.

\section{Soil Measurements (Laboratory)}

During each February sampling period, two soil cores (3.9 $\mathrm{cm}$ diameter and $10 \mathrm{~cm}$ long) were removed from each plot using an aluminum sampling tube that was sharpened at one end. The cores were immediately sealed at both ends with rubber stoppers and placed on ice and returned to the laboratory for removal of interstitial water that was analyzed for salinity, $\mathrm{NO}_{3}-\mathrm{N}, \mathrm{NH}_{4}-\mathrm{N}, \mathrm{pH}$, and sulfide (details below). Following the same sampling schedule, two additional cores were removed from each plot and the cores used for measurements of $\mathrm{N}$-denitrification (details below). Each year, field-based denitrification measurements using cores were made several times (typically three to five) over a 2-week sampling period. Soil cores removed from the plots were replaced by cores collected within $1 \mathrm{~m}$ of each plot.

Soil samples were collected in February 2002, dried $\left(105^{\circ} \mathrm{C}, 48 \mathrm{~h}\right)$, ground and analyzed for Total $\mathrm{N}$, Total $\mathrm{P}$, and Total $\mathrm{K}$ after digestion with a modified Kjeldahl approach (Bremner and Mulvaney 1982).

In the laboratory, interstitial water was collected from cores by extruding the soil from the sampling tubes into plastic sandwich bags that were flushed with $\mathrm{N}$ and sealed. A ceramic soil sipper (Rhizon soil moisture samplers: Model 12.01.SA, Eijkelkamp, Giesbeek, The Netherlands) was inserted into each core through the plastic bag. Sippers were connected to $50 \mathrm{ml}$ syringes and suction was placed onto each syringe by pulling the plunger and fixing it into position with a stopper. Interstitial water collected from one core from each plot was analyzed for salinity (AO Spencer hand-held refractometer) and $\mathrm{pH}$ (Oakton $\mathrm{pH} 510$ Series $\mathrm{pH} / \mathrm{mV} /{ }^{\circ} \mathrm{C}$ meter). We measured sulfide in 2001 following procedures described in McKee et al. (1988) but sulfide was not detected in any of the samples so we did not measure sulfide in 2002 or 2003. For comparative purposes we also sampled deeper interstitial water (@50 cm) in 2001 and measured sulfide levels of 0.05 and $0.85 \mathrm{mM}$.

Interstitial water from the second core from each site was filtered through a $45-\mu \mathrm{m}$ filter, frozen, returned to SERC, and analyzed for $\mathrm{NO}_{3}-\mathrm{N}$ and $\mathrm{NH}_{4}-\mathrm{N}$ using standard APHI methods 303-A173 and 303-S021, respectively (APHA 1995). Samples were analyzed with an Astoria-Pacific International Model 300 automated colorimetric analysis system.

Denitrification was measured on cores using the acetylene block method as described in Hefting et al. (2004). Briefly, the procedure involved incubating soil cores in gas- 
tight jars that were flushed with nitrogen gas prior to adding acetone-free acetylene. Jars were incubated at $20^{\circ} \mathrm{C}$ and gas samples from the head space collected after $20 \mathrm{~h}$. The gas samples were analyzed at Utrecht University in a GC Varian 3300 gas chromatograph equipped with an electron capture detector and Porapak Q columns. In February 2003, we also measured denitrification using cores collected from a separate set of $1 \times 1 \mathrm{~m}$ plots. Six plots served as controls and received 51 of IRL water. The other six received 51 of IRL water in which $1 \mathrm{~g} \mathrm{~N} \mathrm{~m}^{-2}$ had been dissolved. The purpose of this effort was to determine if there were any temporal effects of $\mathrm{N}$ addition by comparing plots that had been fertilized for 2 years with plots that received a onetime fertilization.

\section{Soil Measurements (Field)}

In 2001, we measured Eh and soil temperatures in each plot at a depth of $10 \mathrm{~cm}$. Eh was measured with calibrated platinum electrodes as described by Faulkner et al. (1989) and soil temperatures were recorded with a Eijkelkemp soil thermometer. Eh measurements in the field were adjusted (McKee et al. 1988) by adding $+244 \mathrm{mV}$ (the potential of a calomel reference electrode) to each field measurement.

In all 3 years, nitrous oxide emission rates from each plot were measured using closed flux chambers with an inner diameter of $24.5 \mathrm{~cm}$ and a height of $20 \mathrm{~cm}$. Each chamber had a hole in the top into which a two-hole rubber stopper was placed. Tubing was used to connect the chamber, through the stopper, to an INNOVA Model 1312 photoacoustic multi-gas monitor (TGA, INNOVA, Denmark). Prior to measurements, the flux chambers (one per plot) were inserted into the soil by placing the chamber in the plot and cutting a shallow trench around the chamber with a sharp knife. The chamber was then pushed into the shallow trench to exclude exchange with the atmosphere. The height of the headspace above the soil was measured to determine the headspace volume of each flux chamber. Annually, measurements were made over a period of approximately 2 weeks. The chambers were rotated back and forth between plots (six plots were measured one day and the second set of six plots was made the following day) so that multiple measurements were made on each plot during a 2-week period. The number of measurements per plot over a period of approximately 2 weeks was eight in 2001 and three in 2003. In 2002, we were only able to make one set of measurements on each plot because the impoundment was flooded for most of the 2-week period and measurements could only be made when the water level as at or below the soil surface.

Once the chambers were connected to the photoacoustic multi-gas monitor, they were covered with aluminum foil and nitrous oxide flux was measured. The duration of the measurement period for each chamber was determined by how long it took for the $\mathrm{N}_{2} \mathrm{O}$ concentration to stabilize. Nitrous oxide emissions were calculated from the increase in $\mathrm{N}_{2} \mathrm{O}$ concentration over time from linear regression analysis. Ambus and Robertson (1998) demonstrated that TGA-based measurements of soil $\mathrm{N}_{2} \mathrm{O}$ flux were statistically identical to conventional ECD gas chromatography method.

Nitrogen fixation was measured in each plot in February and July 2002 and February 2003 by exposing duplicate, 10 -g soil samples from each plot to $10 \%$ acetylene and measuring ethylene production (Hardy et al. 1968). Each soil core was taken from $0-5-\mathrm{cm}$ depth and immediately placed intact into a $125-\mathrm{ml}$ canning jar fitted with a rubber septum. The jar was injected with acetylene and placed into the hole left by the soil core to incubate at in situ temperatures. The headspace was sampled three times over the next $24 \mathrm{~h}$ and stored in pre-evacuated Hungate tubes. Headspace gas samples were returned to SERC and analyzed for ethylene with flame ionization detection on a Shimadzu GC-14A gas chromatograph (Shimadzu Instruments, Inc) and a Poropak N (mesh 80-100) column. Fluxes were calculated from the slope of a least-squares regression of ethylene concentration versus time in each jar and expressed as a function of soil mass determined by drying at $110^{\circ} \mathrm{C}$. Fluxes from replicate jars in a plot were averaged so that the true replication was $n=6$. In order to facilitate comparisons with the literature, ethylene flux was converted to $\mathrm{N}$ flux assuming a theoretical ratio of $3 \mathrm{~mol}$ ethylene produced per $1 \mathrm{~mol}$ of $\mathrm{N}_{2}$ fixed, and expressed on an area basis using soil bulk density data from the study site $\left(1.21 \mathrm{~g} \mathrm{~cm}^{-3}\right)$ to a depth of $5 \mathrm{~cm}$.

\section{Statistical Analyses}

Analysis of variance (ANOVA) was used to compare time (year) and treatment (fertilized versus control) as main effects and interactions between time and treatment (SAS Institute 2002-2004). Variables used in the ANOVA were: rate of denitrification (separately for core and chamber studies), rate of nitrogen fixation, growth of tagged Avicennia shoots, number of leaves produced per year on tagged Avicennia shoots, number of branches produced per year on tagged Avicennia shoots, and the nitrogen content of senesced Avicennia leaves. Analyses were performed on transformed data. Means were compared using Tukey's test and the LM Means procedure was used to compare means when there was a significant interaction term in the ANOVA. ANOVA was also used to compare denitrification data for plots that had been fertilized in 2001, 2002, and 2003 with plots that were only fertilized in 2003. One-way ANOVA was used to compare Total N, Total P, Total K and $\mathrm{N}: \mathrm{P}$ of soils collected from control and treatment plots in February 2002. 


\section{Results}

About $1 \mathrm{~h}$ after the first addition of IRL water to the plots, the fertilized and control plots were similar in all measured characteristics except nitrate concentration in interstitial water (Table 1). Other than nitrate, none of the physiochemical soil variables differed substantially between control and fertilized plots in any year.

In addition to the single dwarf black mangrove in each plot, the only other vascular plants in the plots at the beginning of the study were $B$. maritima and two species of Salicornia (S. virginica and S. bigelowii). Densities of Batis and percent cover of Salicornia (almost all plants were the perennial $S$. virginica) did not differ noticeably at the start of the experiment. We also made an initial sampling of senescing leaves of the black mangroves and there were no differences among the controls and treatments in the concentrations of $\mathrm{N}$ (Table 1).

Eh was only measured in 2001 and there was no statistical difference between control $(93.8 \pm 10.6 \mathrm{mV})$ and fertilized plots $(131.4 \pm 13.3 \mathrm{mV})$. Eh measurements indicated that the surface $10 \mathrm{~cm}$ of the substrate was not reduced.

Salinity varied markedly between years but not between treatments and there was no treatment $\times$ year interaction (Table 2). Salinity in February $2003(80.9 \pm 1.7)$ was almost double the mean salinity in $2002(46.0 \pm 1.1)$, which was substantially less than the mean salinity in $2001(58.8 \pm 0.8)$.

Table 2 Results of ANOVA for soil chemical properties

\begin{tabular}{|c|c|c|c|}
\hline & $d f$ & $F$ & $P$ \\
\hline Interstitial water salinity & 5 & 82.43 & 0.0001 \\
\hline Year & 2 & 204.23 & 0.0001 \\
\hline Treatment & 1 & 3.27 & 0.0736 \\
\hline Year $\times$ treatment & 2 & 0.21 & 0.8108 \\
\hline Interstitial water $\mathrm{NO}_{3}$ & 5 & 2.15 & 0.0648 \\
\hline Year & 2 & 1.22 & 0.2984 \\
\hline Treatment & 1 & 6.82 & 0.0103 \\
\hline Year $\times$ treatment & 2 & 0.85 & 0.4306 \\
\hline Interstitial water $\mathrm{NH}_{4}$ & 5 & 3.60 & 0.0048 \\
\hline Year & 2 & 5.19 & 0.0071 \\
\hline Treatment & 1 & 2.72 & 0.1020 \\
\hline Year $\times$ treatment & 2 & 2.89 & 0.0597 \\
\hline Interstitial water $\mathrm{pH}$ & 5 & 0.82 & 0.5376 \\
\hline Year & 2 & 1.01 & 0.3675 \\
\hline Treatment & & 0.82 & 0.3675 \\
\hline Year $\times$ treatment & 2 & 0.10 & 0.8948 \\
\hline Total soil $\mathrm{N}$ & 1 & 0.000 & 0.954 \\
\hline Total soil $\mathrm{P}$ & 1 & 0.02 & 0.8902 \\
\hline Total soil K & 1 & 0.08 & 0.7811 \\
\hline Soil N:P & 1 & 0.00 & 0.9696 \\
\hline
\end{tabular}

Table 3 Results of ANOVA for core and chamber flux measurements of $\mathrm{N}_{2} \mathrm{O}$ and for black mangrove parameters measures in control and treatment plots

\begin{tabular}{|c|c|c|c|}
\hline & $d f$ & $F$ & $P$ \\
\hline $\mathrm{N}_{2} \mathrm{O}$ - cores & 5 & 44.53 & 0.0001 \\
\hline Year & 2 & 3.81 & 0.0336 \\
\hline Treatment & 1 & 214.60 & 0.0001 \\
\hline Year $\times$ treatment & 2 & 0.21 & 0.8090 \\
\hline $\mathrm{N}_{2} \mathrm{O}$ - chambers & 5 & 12.00 & 0.0001 \\
\hline Year & 2 & 9.32 & 0.0007 \\
\hline Treatment & 1 & 36.53 & 0.0001 \\
\hline Year $\times$ treatment & 2 & 2.43 & 0.1056 \\
\hline $\mathrm{N}$ fixation & 5 & 16.10 & 0.001 \\
\hline Year & 2 & 7.45 & 0.0012 \\
\hline Treatment & 1 & 63.88 & 0.0001 \\
\hline Year $\times$ treatment & 2 & 0.88 & 0.4216 \\
\hline $\mathrm{N}_{2} \mathrm{O}$ - cores (compare year 1 with year 2 ) & 3 & 15.20 & 0.0001 \\
\hline Time ( 1 versus 2 years) & 1 & 7.02 & 0.0154 \\
\hline Treatment & 1 & 37.13 & 0.0001 \\
\hline Time $\times$ treatment & 1 & 1.44 & 0.2443 \\
\hline Avicennia shoot growth & 3 & 1.09 & 0.3608 \\
\hline Year & 1 & 0.58 & 0.4500 \\
\hline Treatment & 1 & 1.64 & 0.2045 \\
\hline Year $\times$ treatment & 1 & 1.67 & 0.1999 \\
\hline Number of new Avicennia leaves & 3 & 2.36 & 0.0783 \\
\hline Year & 1 & 5.03 & 0.0280 \\
\hline Treatment & 1 & 2.23 & 0.1398 \\
\hline Year $\times$ treatment & 1 & 0.00 & 0.9669 \\
\hline Number of new Avicennia branches & 3 & 4.73 & 0.0045 \\
\hline Year & 1 & 8.06 & 0.0059 \\
\hline Treatment & 1 & 6.63 & 0.0121 \\
\hline Year $\times$ treatment & 1 & 0.02 & 0.8957 \\
\hline $\mathrm{N}$ in senesced Avicennia leaves & 3 & 0.42 & 0.7432 \\
\hline Year & 1 & 1.14 & 0.3005 \\
\hline Treatment & 1 & 0.07 & 0.7972 \\
\hline Year $\times$ treatment & 1 & 0.01 & 0.9255 \\
\hline
\end{tabular}

There were no pronounced effects of the treatments on the $\mathrm{pH}$ of interstitial water (Table 2). The $\mathrm{pH}$ differed little between years $(2001=7.61 \pm 0.03,2002=7.60 \pm 0.02,2003=$ $7.55 \pm 0.02$ ) or treatments (control $=7.56 \pm 0.03$, fertilized $=$ $7.61 \pm 0.02)$

Nitrate concentrations in interstitial water were higher in the fertilized plots (fertilized $=1.89 \pm 0.35 \mathrm{mg} / \mathrm{l}$; control= $0.87 \pm 0.22 \mathrm{mg} / \mathrm{l})$ and the means differed across the 3 years (data not shown) but there was not a significant overall model effect (Table 2). There was a distinct model effect for ammonium with a significant year and year $\times$ treatment interaction (Table 2). Ammonium concentrations were noticeably lower in $2003(0.81 \pm 0.07 \mathrm{mg} / \mathrm{l})$ compared to similar values in $2001(1.10 \pm 0.09)$ and $2002(1.02 \pm 0.07)$. 
The significant interaction was due to higher ammonium concentrations in the control plots in 2001 and $2002(1.05 \pm$ 0.11 and $1.15 \pm 0.11$, respectively) and higher concentrations in fertilized plots in $2002(1.18 \pm 0.14)$.

Soil samples collected in February 2002 were analyzed for Total N, P, and $\mathrm{K}$ to determine if there had been any effects after 1 year of the experimental treatments on total standing stocks of nutrients in the top $10 \mathrm{~cm}$ of the plots. There were no significant differences (Table 2) between treatments for $\mathrm{N}$ (control $=0.60 \pm 0.09 \mathrm{mg} / \mathrm{g}$ dry soil; fertilized $=0.58 \pm 0.06$ ), $\mathrm{P}$ (control $=0.71 \pm 0.01 \mathrm{mg} / \mathrm{g}$ dry soil; fertilized $=0.71 \pm 0.01$ ) or $\mathrm{K}$ (control $=0.55 \pm 0.03 \mathrm{mg} / \mathrm{g}$ dry soil; fertilized $=0.54 \pm 0.04$ ) and the ratio of $\mathrm{N}: \mathrm{P}$ (control= $0.85 \pm 0.12$; fertilized $=0.82 \pm 0.08$ ).

\section{Denitrification and Nitrous Oxide Emission}

There were significant year and treatment effects on denitrification as measured through lab incubations of cores and nitrous oxide emissions measured in field chambers but the interaction between year and treatment was not significant for either method (Table 3). For 10-cm-deep soil cores (Fig. 1a), denitrification was much higher in fertilized $\left(2.46 \pm 0.27 \mathrm{mg} \mathrm{N} / \mathrm{m}^{2} / \mathrm{h}\right)$ compared to control
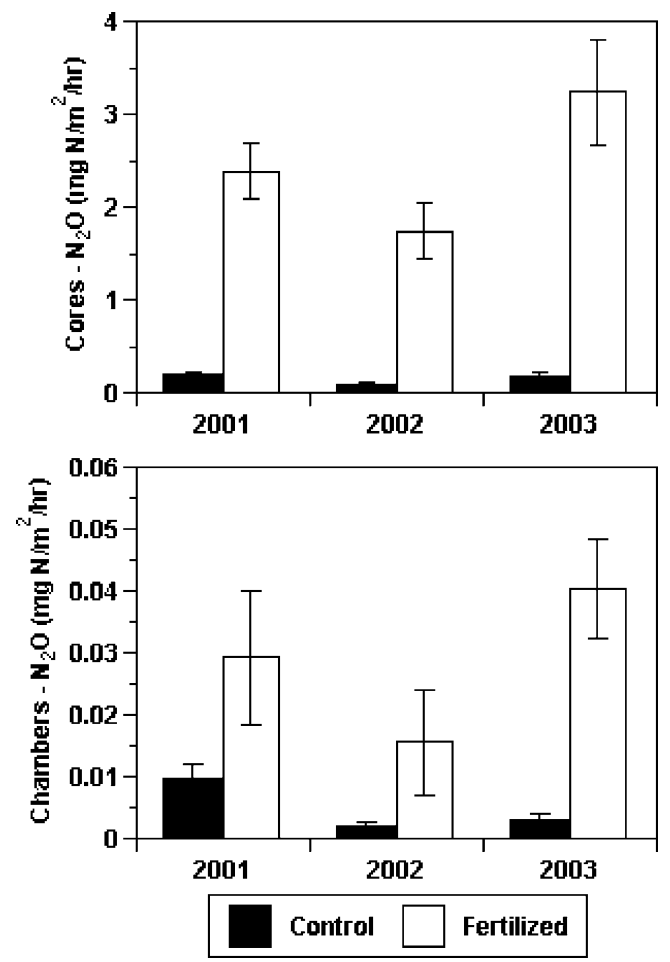

Fig. 1 Denitrification rates from cores incubated in the lab and $\mathrm{N}_{2} \mathrm{O}$ fluxes measured in field chambers. Values are means \pm 1 standard error. The means for fertilized plots differed significantly from Control plots in all 3 years for both measurement techniques and there were no significant interactions between treatment and time (Table 3)
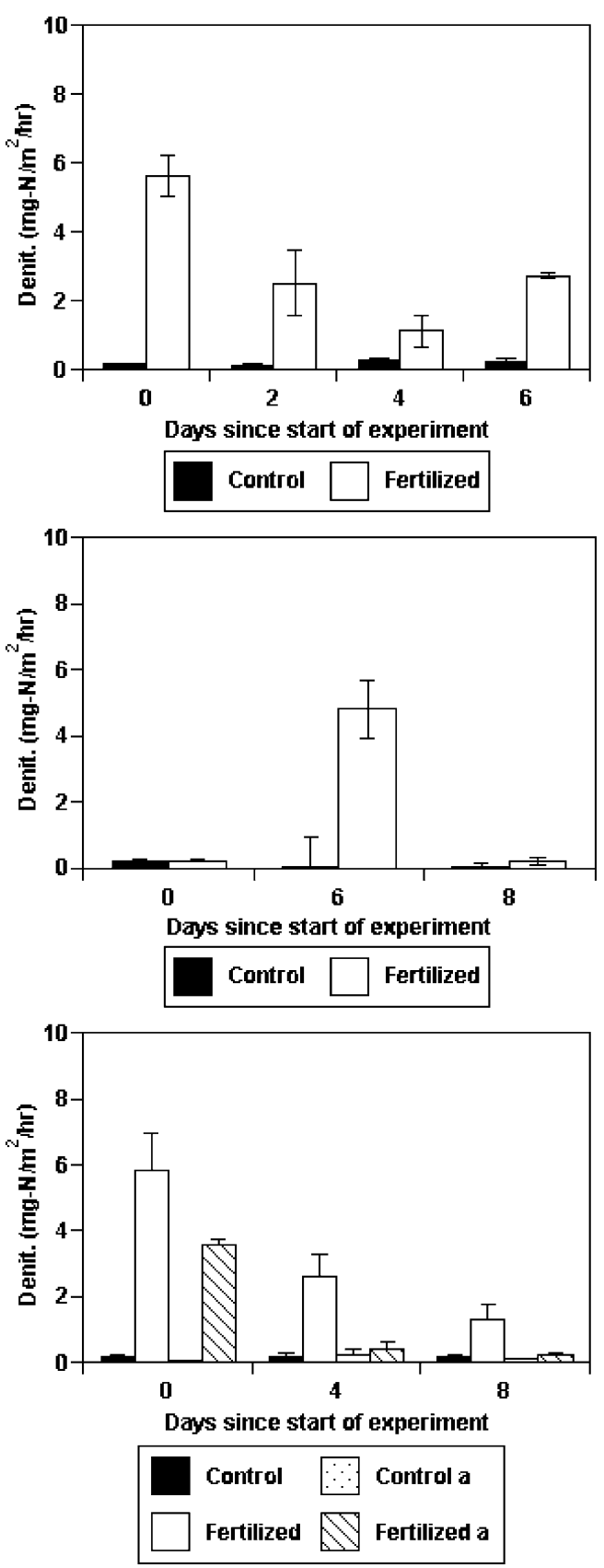

Fig. 2 Rates of denitrification in cores in 2001-2003. Values are means \pm 1 standard error. In 2003, we also measured denitrification (see "Methods" section) in a second set of sites (Fertilized a and Control a) that were used to determine if the application of $\mathrm{N}$ to sites had resulted in any long-term changes in the rate of denitrification

$\left(0.16 \pm 0.03 \mathrm{mg} / \mathrm{m}^{2} / \mathrm{h}\right)$ plots and the measured rates differed between years (data not shown)

Nitrous oxide emission rates from chambers (Fig. 1b) were almost six times higher in fertilized plots $(0.028 \pm$ 0.006 compared to $0.005 \pm 0.001$ in control plots). The $\mathrm{N}_{2} \mathrm{O}$ fluxes from chambers also varied between years of measurements; being substantially lower in $2002(0.009 \pm$ 

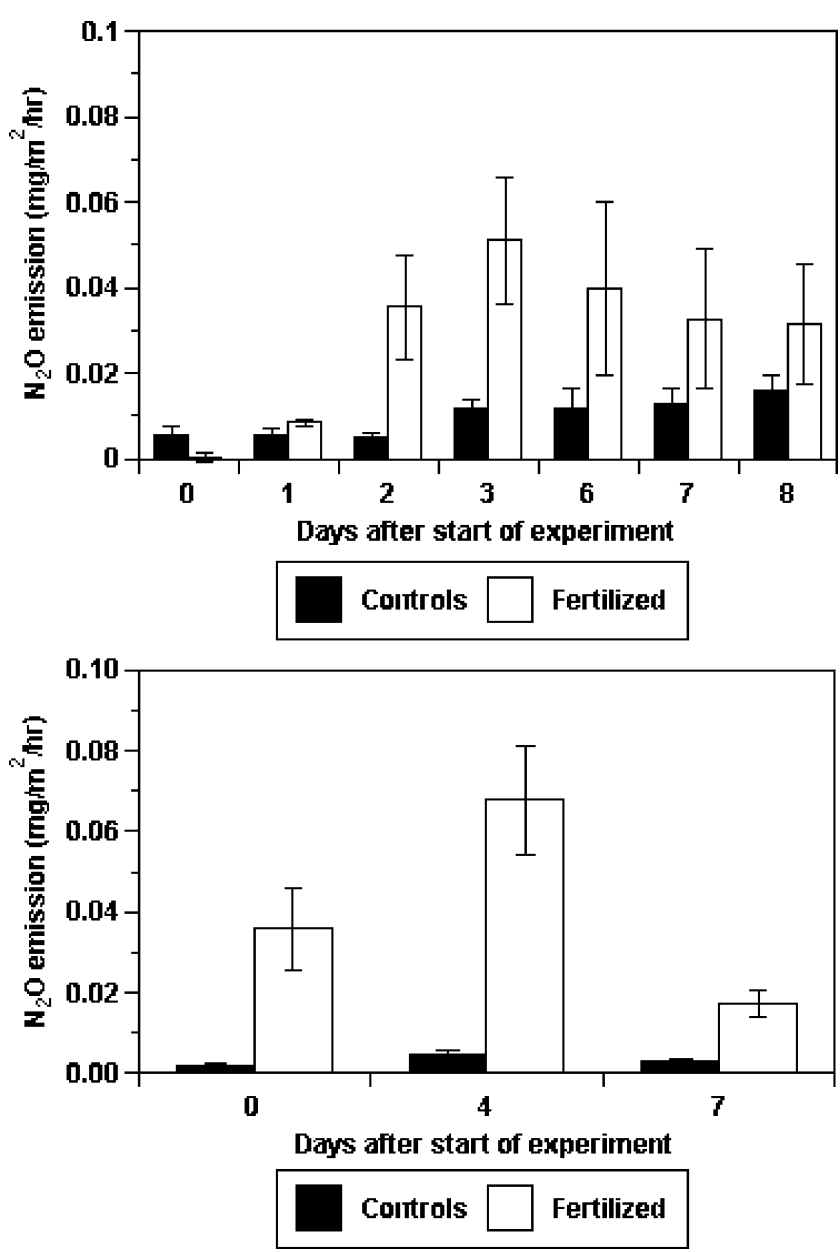

Fig. 3 Rates of nitrous oxide emissions in 2001 and 2003. Values are means \pm 1 standard error

$0.005)$ compared to $2001(0.019 \pm 0.006)$ and $2003(0.021 \pm$ $0.007)$.

In 2003, we measured denitrification from cores in a separate set of 12 plots (see the "Methods" section) to compare rates after 2 years of fertilization with rates of denitrification after a single application of fertilizer. There were significant treatment and year differences observed, but the interaction term was not statistically significant (Table 3). Denitrification was about eight times higher in fertilized plots $\left(2.33 \pm 0.48 \mathrm{mg} / \mathrm{m}^{2} / \mathrm{h}\right.$ compared to $0.16 \pm$ $0.04 \mathrm{mg} / \mathrm{m}^{2} / \mathrm{h}$ in control plots) and plots that had been fertilized for 2 years had higher rates of denitrification $\left(1.72 \pm 0.53 \mathrm{mg} / \mathrm{m}^{2} / \mathrm{h}\right)$ compared to plots that only received one application of fertilizer $\left(0.77 \pm 0.34 \mathrm{mg} / \mathrm{m}^{2} / \mathrm{h}\right)$

The time-courses of denitrification (Fig. 2) and $\mathrm{N}_{2} \mathrm{O}$ emissions (Fig. 3) were also similar across the course of the experiment. For the soil cores, the rate of denitrification in the fertilized plots increased sharply within $1 \mathrm{~h}$ of application of the $\mathrm{N}$ (day 0 ) and decreased gradually in a few days afterwards in 2001 and 2003. In 2002, the site (see above) was flooded during most of the 2-week study period and the peak measurement was delayed until the second set of measurements on day 6 (Fig. 2b). $\mathrm{N}_{2} \mathrm{O}$ emissions from the chambers peaked 3-4 days after the fertilizer was added in 2001 and 2003 (Fig. 3). Only one measurement of $\mathrm{N}_{2} \mathrm{O}$ emission was made in 2002 because of surface flooding of the plots.

\section{Nitrogen Fixation}

Nitrogen fixation was measured in February 2002 and 2003 and July 2002 (Fig. 4). There was a significant treatment and time effects on the rate of nitrogen fixation, and no significant interactions between treatment and time (Table 3). For 5-cm-deep soil cores, and averaging across all months, $\mathrm{N}_{2}$ fixation was substantially lower in fertilized than control plots $(0.041 \pm 0.022$ versus $0.331 \pm 0.080 \mathrm{mg} \mathrm{N} /$ $\mathrm{m}^{2} /$ day). Averaging across treatments, rates measured in February $2003\left(0.098 \pm 0.049 \mathrm{mg} \mathrm{N} / \mathrm{m}^{2} /\right.$ day $)$ were noticeably lower than rates measured in February $2002(0.203 \pm$ $0.054 \mathrm{mg} \mathrm{N} / \mathrm{m}^{2} /$ day $)$ and July $2002(0.186 \pm 0.059 \mathrm{mg}$ $\left.\mathrm{N} / \mathrm{m}^{2} / \mathrm{h}\right)$.

\section{Black Mangrove Measurements}

There was no significant experimental effect on annual shoot growth, the number of new leaves produced on the tagged Avicennia shoots, or the $\mathrm{N}$ concentration of recently senesced leaves (Table 3 and Fig. 5). There was a significant year and treatment effect on the number of new branches on the tagged shoots with shoots on fertilized plants producing more branches per year $(0.92 \pm 0.20=$ fertilized; $0.36 \pm 0.89=$ control) and a significantly greater number of branches produced in year $1(0.81 \pm 0.16)$ compared to year $2(0.43 \pm 0.14)$.

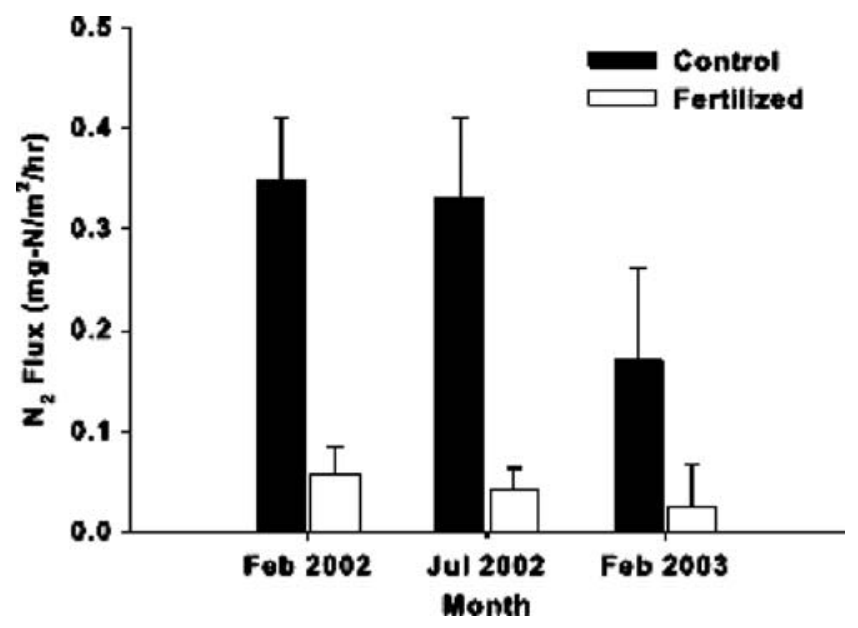

Fig. 4 N-fixation from Control and Fertilized plots.Values are means \pm 1 standard error 
Fig. 5 Shoot growth, the number of new leaves, the number of branches per shoot, and $\% \mathrm{~N}$ of senesced leaves on tagged Avicennia germinans shoots. Values are means \pm 1 standard error
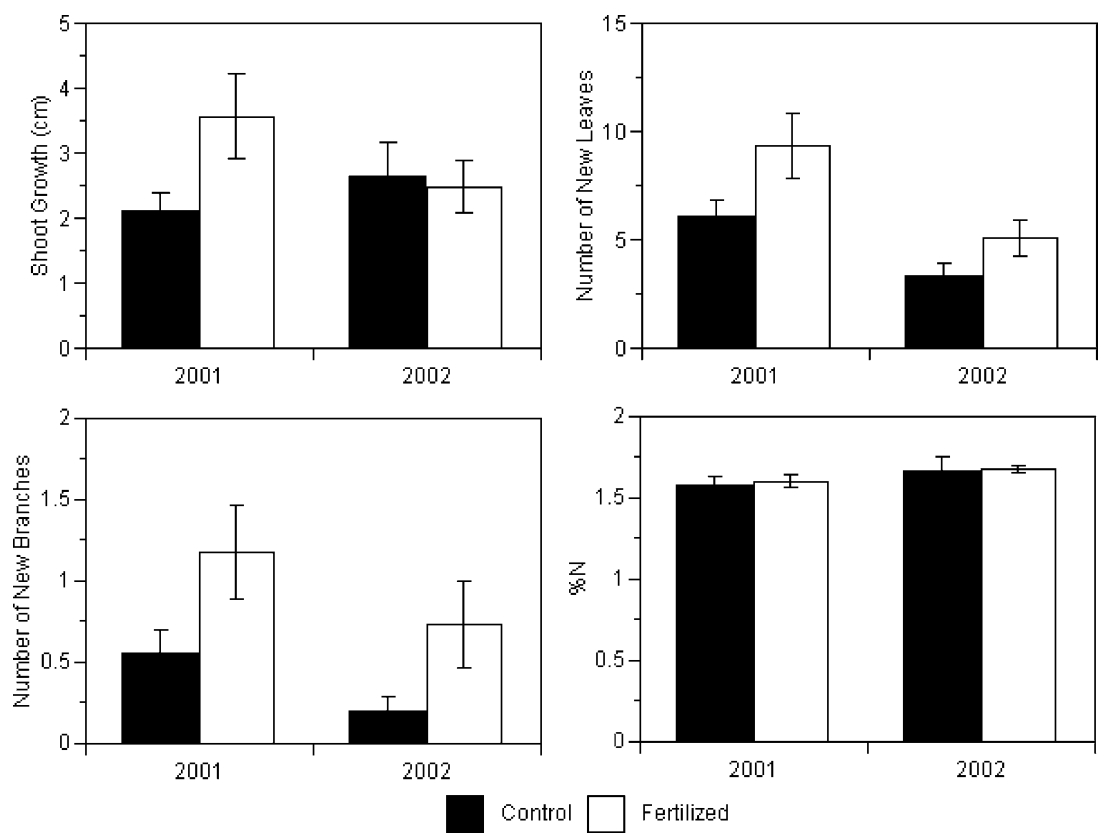

\section{Discussion}

Historically, dwarf growth forms of mangrove trees have been associated with a variety of factors including high salinity, poorly aerated sulfate-rich and compacted soils, and nutrient limitations (e.g., Lugo and Snedaker 1974; Tomlinson 1986; McKee 1993; Ball 1996; Nandoo 2006). Whether or not individual factors or suites of interrelated factors are responsible for dwarf growth forms remains an open question, but recent nutrient-addition experiments have shed light on some of the key factors. Feller and colleagues (Feller 1995; Feller et al. 2002; McKee et al. 2002; Feller et al. 2003; Lovelock et al. 2006a, b, 2007) have been conducting a series of nutrient-addition experiments in mangroves in Florida, Belize, Panama, New Zealand, and Australia. They found that the addition of a limiting nutrient (nitrogen, phosphorus or a combination of $\mathrm{N}$ and $\mathrm{P}$ ) at all study sites resulted in a substantial increase in growth and an especially dramatic increase in the growth of shoots of dwarf mangroves. The underlying mechanisms thought to be responsible for the dramatic growth response of dwarf growth forms (e.g., as much as a tenfold increase in annual shoot elongation) were summarized by Lovelock et al. (2006a, b). In P-limited habitats, a significant increase in several growth-related measurements was associated with an increase in water conductance which, in turn, was associated with an increase in the average diameter of water-conducting vessels in red mangrove shoots. Stomatal conductance and photosynthetic rates of dwarf red mangrove shoots also increased to levels that where similar to much taller trees in fringe habitats (Lovelock et al. 2006a).
In the same area where the current study was conducted, Lovelock et al. (2006b) measured a sevenfold increase in shoot growth in dwarf $A$. germinans compared to dwarf $L$. racemosa following the addition of $\mathrm{N}$. Even though there were dramatic differences in growth, there were no differences in stem hydraulic conductivity and the only difference between the two species was that leaf-specific conductance was higher in A. germinans. Lovelock et al. concluded that the response of $A$. germinans was primarily due to the allocation of biomass to leaf area, as a lower leaf area per unit of water consumption may result in less vulnerability to xylem embolism.

The most striking response of Avicennia to $\mathrm{N}$ addition in our study was the lack of a clear and dramatic growth response (Fig. 5 and Table 3) in all the parameters measured. Shoot growth, the number of new leaves, and the number of branches per shoot were all higher in $\mathrm{N}$ fertilized plants (Fig. 5) but the differences were only significant for the number of branches (Table 3). Also, in contrast to the distinctly higher $\mathrm{N}$ content of senesced leaves of fertilized Avicennia in the adjacent impoundment (Feller et al. 2003), the means for fertilized and control plants were almost identical in this experiment (Fig. 5).

The reasons for the lack of clear growth responses of dwarf Avicennia in this study are unknown but at least two factors need to be considered. First, our study sites were distinctly hypersaline (57; see Table 1). Increases in salinity have been shown to have a negative effect on growth, mortality, and hydraulic conductivity of A. germinans (Suárez and Medina 2005; Lovelock et al. 2006b). However, there is also evidence that seedlings and dwarf growth forms of black mangrove are adapted to higher 
salinities and higher ambient light conditions (Christian 2005), are capable of maintaining adequate water uptake under hypersaline conditions (Sobrado and Ewe 2006), and experience minimal effects on growth at salinities up to at least 35 (Ye et al. 2005). Feller et al. (2003) found that black mangrove responded positively to $\mathrm{N}$ addition at salinities that averaged 41-57 and that there was an almost tenfold increase in growth of fertilized dwarf black mangroves at the sites with the highest salinities. It does not, therefore, seem likely, that the lack of a significant growth response of trees in this study was due to hypersaline conditions.

The mode of fertilizer application is another factor that may be related to the lack of a strong growth response of dwarf black mangroves in this study. The inter-continental fertilization experiments being conducted by Feller and colleagues (see citations above) employ the addition of a slow-release $\mathrm{N}$ fertilizer into 30-cm-deep holes that are then plugged with the substrate that was removed to make the hole. The goal of this application procedure was to make the fertilizer available to the tree roots. The $\mathrm{N}$ fertilizer used in their experiments is urea (N:P:K, 45:0:0) and it is placed into dialysis tubing before it is inserted into the holes. This mode of application results in the slow release of $\mathrm{N}$ at depths that is probably below the surface microbial community.

In this study, we applied $\mathrm{N}$ at the same annual rate that is used in the study by Feller and colleagues, but the form of the fertilizer was different. We applied the $\mathrm{N}$ as $\mathrm{NaNO}_{3}$ dissolved in 51 of estuarine water that was sprinkled onto the soil surface when the substrate was not flooded; thus ensuring that the $\mathrm{NO}_{3}$ infiltrated the substrate. Our goal was to mimic an increase in nitrate input in tidal flooding that would be associated with increased eutrophication of the Indian River. We anticipated that the added nitrogen would be available to the microbial community in the surface soils where most of the $\mathrm{N}$ retention and losses from mangrove soils apparently occur (Chiu et al. 2004).

A portion of the microbial community involved in $\mathrm{N}$ cycling responded rapidly to the addition of $\mathrm{NO}_{3}$ to the surface of the soil by increasing the rates of denitrification and $\mathrm{N}_{2} \mathrm{O}$ emission. Denitrification increased within an hour of addition of the $\mathrm{NO}_{3}$ in 2001 and 2003 (Fig. 2). The denitrification response was delayed in 2002, probably because the groundwater was at or very close to the soil surface at the time the $\mathrm{N}$ was added.

Rapid uptake of $\mathrm{N}$ by the microbial community in mangroves has previously been measured (Corredor et al. 1999). Others found that mangrove soils were a sink for $\mathrm{N}$ due to microbial assimilation, especially in vegetated sites (e.g., Rivera-Monroy et al. 1995; Kristensen et al. 1998). We also found that the rates of denitrification were higher in plots that had been fertilized for 1 year compared to plots that had not been previously fertilized (see the "Results" section), suggesting that the biomass or denitrifying enzyme content of the denitrifying microbial community increased over time, even though nitrate additions to the soil were episodic.

While we did not attempt to separate $\mathrm{N}$ uptake by plants versus microorganisms, a comparison of our results to those of Feller and colleagues, clearly suggests that the $\mathrm{N}$ that was added was mostly assimilated and processed by the microbial community. Our study suggests that mangrove systems in the N-limited (Feller et al. 2002) Indian River Lagoon are likely to be long-term sinks for any increases in $\mathrm{N}$ loading that result from local cultural eutrophication. The microbial community is clearly an important component of $\mathrm{N}$-processing and the dwarf mangroves in the interior of the wetlands are likely to remain $\mathrm{N}$-limited unless or until $\mathrm{N}$ addition to the lagoon reaches much higher level. $\mathrm{N}_{2} \mathrm{O}$ fluxes in non-fertilized plots of studied hypersaline mangrove wetland are currently within the range reported for other pristine mangroves (Barnes et al. 2006). Enhancing $\mathrm{N}$ loading of the lagoon will stimulate nitrification and denitrification in mangrove soils and increase $\mathrm{N}_{2} \mathrm{O}$ flux to the atmosphere.

The long-term availability of $\mathrm{N}$ in mangrove systems is also determined by the extent to which outputs are balanced by inputs from tides, atmospheric deposition, and microbial $\mathrm{N}_{2}$ fixation. $\mathrm{N}_{2}$ fixation rates are governed by the availability of carbon (i.e., energy), soil $\mathrm{NH}_{4}^{+}$availability, and other factors (Holguin et al. 2001). In control plots, rates of $\mathrm{N}_{2}$ fixation exceeded denitrification by twofold even though the $\mathrm{N}_{2}$ fixation cores where only half as deep $(5 \mathrm{~cm}$ versus $10 \mathrm{~cm})$. This suggests these sites are either accumulating $\mathrm{N}$ or acting a net source of $\mathrm{N}$ to the surrounding system. Rates of both $\mathrm{N}_{2}$ fixation and denitrification were at the low end of the range of previously reported values for mangrove soils (Lee and Joye 2006). The low rates at our site may be caused by hypersaline conditions (Table 1) or rapid desiccation of the sandy soils between flood events.

We found that $\mathrm{N}$ fertilization suppressed inputs from $\mathrm{N}_{2}$ fixation, a potentially important $\mathrm{N}$ source, by about $75 \%$. This $0.24 \mathrm{mg} \mathrm{N} / \mathrm{m}^{2} / \mathrm{h}$ decline in $\mathrm{N}_{2}$ fixation inputs was small compared to the $2.3 \mathrm{mg} \mathrm{N} / \mathrm{m}^{2} / \mathrm{h}$ increase in denitrification, indicating that denitrification is the more important process to consider for mitigation of cultural $\mathrm{N}$ eutrophication.

Acknowledgments The research was supported by grants from the Smithsonian Marine Station at Ft. Pierce (SMSFP) and by resources of the Smithsonian Environmental Research Center and Utrecht University. We thank Paul van der Ven, Kim Givler, Amy Wolf, and Jay O'Neill for assistance with the field work and analytical processing of samples. Special thanks to Val Paul, Woody Lee, and support staff at SMSFP for ensuring the success of the project.

Open Access This article is distributed under the terms of the Creative Commons Attribution Noncommercial License which permits any noncommercial use, distribution, and reproduction in any medium, provided the original author(s) and source are credited. 


\section{References}

APHA (American Public Health Association). 1995. Standard methods for the examination of water and wastewater. Washington: APHA.

Allen, D.E., R.C. Dalal, H. Rennenberg, R.L. Meyer, S. Reeves, and S. Schmidt. 2007. Spatial and temporal variation of nitrous oxide and methane flux between subtropical mangrove sediments and the atmosphere. Soil Biology and Biochemistry 39: 622-631.

Alongi, D.M., J. Pfitzner, L.A. Trott, F. Tirendi, P. Dixon, and D.W. Klumpp. 2005. Rapid sediment accumulation and microbial mineralization in forests of the mangrove Kandelia candel in the Jiulongjiang Estuary China. Estuarine Coastal and Shelf Science 63: 605-618.

Ambus, P. and G.P. Robertson. 1998. Automated near continuous measurement of carbon dioxide and nitrous oxide fluxes from soil. Soil Science Society America Journal 62: 394-400.

Ball, M.C. 1996. Comparative ecophysiology of mangrove forest and tropical lowland moist forest. In Plant ecophysiology, ed. S.S. Muleky, R.L. Chazdon, and A.P. Smith, 461-496. New York: Chapman and Hall.

Barnes, J., R. Ramesh, R. Purvaja, A. Nirmal Rajkumar, B. Senthil Kumar, K. Krithika, K. Ravichandran, G.Uher, and R. N. UpstillGoddard. 2006. Tidal dynamics and rainfall control $\mathrm{N}_{2} \mathrm{O}$ and $\mathrm{CH}_{4}$ emissions from pristine mangrove creek. Geophysical Research Letters 33, L15405: 1-6

Bashan, Y., M.E. Puente, D.D. Myrold, and G. Toledo. 1998. In vitro transfer of fixed nitrogen from diazotropic filamentous cyanobacteria to black mangrove seedlings. FEMS Microbiology Ecology 26: 165-170.

Bauza, J.F., J.M. Morell, and J.E. Corredor. 2002. Biogeochemistry of nitrous oxide production in the red mangrove (Rhizophora mangle) forest sediments. Estuarine, Coastal and Shelf Science 55: 697-704.

Boto, K.G. and J.T. Wellington. 1983. Phosphorus and nitrogen nutritional status of a northern Australian mangrove forest. Marine Ecology Progress Series 11: 63-69.

Bremner, J. M., and C.S. Mulvaney. 1982. Nitrogen-Total. In Methods of Soil Analysis. Part 2. Chemical and Microbiological Properties, 2nd edition, eds. A.L. Page, R.H. Miller, and D.R. Keeney, 595-624. Madison, Wisconsin: American Society of Agronomy, Soil Science Society of America.

Castaneda-Moya, E., V.H. Rivera-Monroy, and R.R. Twilley. 2006. Mangrove zonation in the dry life zone of the Gulf of Fonseca, Honduras. Estuaries and Coasts 29: 751-764.

Chen, R. and R.R. Twilley. 1999. Patterns of mangrove forest structure and soil nutrient dynamics along the Shark River estuary, Florida. Estuaries 22: 955-970.

Chiu, C.-Y., S.-C. Lee, T.H. Chen, and G. Tian. 2004. Denitrification associated N loss in mangrove soil. Nutrient Cycling in Agroecosystems 69: 185-189.

Christian, R. 2005. Interactive effects of salinity and irradiance on photoprotection in acclimated seedlings of two sympatric mangroves. Trees 19: 596-606.

Corredor, J.E., J.M. Morell, and J. Bauza. 1999. Atmospheric nitrous oxide fluxes from mangrove sediments. Marine Pollution Bulletin 38: 473-478.

Faulkner, S.P., W.H. Patrick, and R.P. Gambrell. 1989. Field techniques for measuring wetland soil parameters. Soil Science of America Journal 53: 883-890.

Feller, I.C. 1995. Effects of nutrient enrichment on growth and herbivory of dwarf red mangrove (Rhizophora mangle). Ecological Monographs 65: 477-505.

Feller, I.C., D.F. Whigham, J.P. O’Neill, and K.M. Mckee. 1999. Effects of nutrient enrichment on within-stand nutrient cycling in mangrove ecosystems in Belize. Ecology 80: 2193-2205.
Feller, I.C., D.F. Whigham, K.M. McKee, and J.P. O’Neill. 2002. Nitrogen vs. phosphorus limitation across an ecotonal gradient in a mangrove forest. Biogeochemistry 62: 145-175.

Feller, I.C., D.F. Whigham, K.M. McKee, and C.E. Lovelock. 2003. Nitrogen limitation of growth and nutrient dynamics in a disturbed mangrove forest, Indian River Lagoon, Florida. Oecologia 134: 405-414.

Hardy, R.W.F., R.D. Holsten, E.K. Jackson, and R.C. Burns. 1968. The acetylene-ethylene assay for $\mathrm{N}_{2}$ fixation: laboratory and field evaluation. Plant Physiology 43: 1185-1207.

Hefting, M., J.C. Clément, D. Dowrick, A.C. Cosandey, S. Bernal, C. Cimpian, A. Tatur, T.P. Burt, and G. Pinay. 2004. Water table elevation controls on soil nitrogen cycling in riparian wetlands along a European climatic gradient. Biogeochemistry 67: 113-134.

Hicks, B.J. and W.B. Silvester. 1985. Nitrogen fixation associated with the New Zealand mangrove (Avicennia marina (forsk.) Vierh. Var. resinifera (Forst. F.) Bakh.). Applied and Environmental MicrobioLogy 1985: 955-959.

Holguin, G., P. Vazauez, and Y. Bashan. 2001. The role of sediment microorganisms in then productivity, conservation, and rehabilitation of mangrove ecosystems: an overiew. Biology and Fertility of Soils 33: 265-278.

Joye, S.B. and R.Y. Lee. 2004. Benthic microbial mats: important sources of fixed nitrogen and carbon to the Twin Cays, Belize ecosystem. Atoll Research Bulletin 528: 1-26.

Kristensen, E., M.H. Hensen, G.T. Banta, K. Hansen, M. Holmer, and G.M. King. 1998. Transformation and transport of inorganic nitrogen in sediments of a southeast Asian mangrove forest. Aquatic Microbial Ecology 5: 165-175.

Lara, R.J. and M.C.L. Cohen. 2006. Sediment porewater salinity, inundation frequency and mangrove vegetation height in Bragança, North Brazil: an ecohydrology-based empirical model. Wetlands Ecology and Managment 14: 349-358.

Lee, R.Y. and S.B. Joye. 2006. Seasonal patterns of nitrogen fixation and denitrification in oceanic mangrove habitats. Marine Ecology Progress Series 307: 127-141.

López-Hoffman, L., N.P.R. Anten, M. Martínez-Ramos, and D.D. Ackerly. 2007. Salinity and light interactively affect neotrpical mangrove seedlings at the leaf and whole plant levels. Oecologia 150: $545-556$.

Lovelock, C.E. and I.C. Feller. 2003. Photosynthetic performance and resource utilization of two mangrove species coexisting in a hypersaline scrub forest. Oecologia 34: 455-462.

Lovelock, C.E., M.C. Ball, B. Choat, B.M.J. Engelbrecht, N.M. Holbrook, and I.C. Feller. 2006a. Linking physiological processes with mangrove forest structure: phosphorus deficiency limits canopy development, hydraulic conductivity and photosynthetic carbon gain in dwarf Rhizophora mangle. Plant, Cell and Environment 29: 793-802.

Lovelock, C.E., M.C. Ball, I.C. Feller, B.M.J. Engelbrecht, and M.L. Ewe. 2006b. Variation in hydraulic conductivity of mangroves: influence of species, salinity, and nitrogen and phosphorus availability. Physiologia Plantarum 127: 457-464.

Lovelock, C.E., I.C. Feller, J. Ellis, A.M. Schwarz, N. hancock, P. Nichols, and B. Sorrell. 2007. Mangrove growth in New Zealand estuaries: the role of nutrient enrichment at sites with contrasting rates of sedimentation. Oecologia 153: 633-641.

Lugo, A.E. and S.C. Snedaker. 1974. The ecology of mangroves. Annual Review of Ecology and Systematics 5: 39-64.

McKee, K.L. 1993. Soil physiolchemical patterns and mangrove species distribution-reciprocal effects? Journal of Ecology 81: 477-487.

McKee, K.M., I.A. Mendelssohn, and M.W. Hester. 1988. Reexamination of pore water sulfide concentrations and redox potentials near the aerial roots of Rhizophora mangle and Avicennia germinans. American Journal of Botany 5: 1352-1359. 
McKee, K.M., I.C. Feller, M. Poop, and W. Wanek. 2002. Mangrove isotopic fractionation $\left(\delta^{15} \mathrm{~N}\right.$ and $\left.\delta^{13} \mathrm{C}\right)$ across a nitrogen versus phosphorus limitation gradient. Ecology 83: $1065-1075$.

Muñoz-Hincapié, M., J.M. Morell, and J.E. Corredor. 2002. Increase of nitrous oxide flux to the atmosphere upon nitrogen addition to red mangrove sediments. Marine Pollution Bulletin 44: 992-996.

Nandoo, G. 2006. Factors contributing to dwarfing in the mangrove Avicennia marina. Annals of Botany 97: 1095-1101.

Pelegraí, S.P., V.H. Rivera-Monroy, and R.R. Twilley. 1997. A comparison of nitrogen fixation (acetylene reduction) among three species of mangrove, litter, sediments, and pneumatophores in South Florida, USA. Hydrobiologia 356: 73-79.

Rey, J.R., R.A. Crossman, and T.R. Kain. 1990. Vegetation dynamics in impounded marshes along the Indian River Lagoon, florida, USA. Environmental management 14: 397-409.

Rivera-Monroy, V.H. and R.R. Twilley. 1996. The relative role of denitrification and immobilization in the fate of inorganic nitrogen in mangrove sediments (Terminos Lagoon, Mexico). Limnology and Oceanography 41: 284-296.

Rivera-Monroy, V.H., R.R. TwilleY, R.G. Boustany, J.W. Day, F. Vera-Herrera, and M. del Carmen Ramirez. 1995. Direct denitrification in mangrove sediments in Terminos Lagoon, Mexico. Marine Ecology Progress Series 126: 97-109.

SAS Institute, INC. 2002-2004. SAS 9.1.3 Help and Documentation. Cary: SAS Institute, Inc.

Sobrado, M.A. and M.L. Ewe. 2006. Ecophysiological characteristics of Avicennia germinans and laguncularia racemosa in a scrub mangrove forest at the Indian River Lagoon, Florida. Trees 20: 679-687.

Suárez, N. and E. Medina. 2005. Salinity effect on plant growth and leaf demography of the mangrove, Avicennia germinans L. Trees 19: 721-727.

Toldeo, G., U. Bashan, and A. Soeldner. 1995. In vitro colonization and increase in nitrogen fixation of seedling roots of black mangrove inoculated by a filamentous cyanobacteria. Canadian Journal of Microbiology 41: 1012-1020.

Tomlinson, P.B. 1986. The botany of mangroves. Cambridge: Cambridge University Press.

Ye, Y., N. Fung-Yee Tam, C.-Y. Lu, and U.-S. Wong. 2005. Effects of salinity on germination, seedling growth and physiology of three salt-secreting mangrove species. Aquatic Botany 83: 193-205.

Zuberer, D.A. and W.S. Silver. 1979. $\mathrm{N}_{2}$-fixation (acetylene reduction) and the microbial colonization of mangrove roots. New Phytologist 82: $467-471$. 